\title{
Scytinium pulvinatum comb. nov. (Collemataceae, Peltigerales)
}

\section{Otálora MAG ${ }^{1}$ and Wedin $\mathbf{M}^{1}$}

Department of Botany, Swedish Museum of Natural History, Post-office box 50007, SE-104 05 Stockholm, Sweden. email: monica.garcia.otalora@gmail.com

Otálora MAG, Wedin M 2014 - Scytinium pulvinatum comb. nov. (Collemataceae, Peltigerales). Mycosphere 5(4), 502-503, Doi 10.5943/mycosphere/5/4/1

Abstract

In this paper Collema pulvinatum Hoffm. is synonymized under Scytinium pulvinatum (Hoffm.) Otálora, P.M. Jørg. \& Wedin, providing “Leptogium” pulvinatum with a formal name.

Keywords - Leptogium - synonymy

\section{Introduction}

Recently, Otálora et al (2013) presented a major reclassification of the family Collemataceae. Here the non-monophyletic Collema F.H. Wigg. and Leptogium (Ach.) Gray where re-circumscribed, and a number of phylogenetically and morphologically distinguishable genera were resurrected, or, in a few cases, newly described. Scytinium (Ach.) Gray was taken up for the small former Leptogium species, a consequence of the proposed conservation of Leptogium with a new type (Jørgensen et al., 2013). Among the names combined into Scytinium, one unfortunate omission was made, which leaves "Leptogium" pulvinatum (Hoffm.) Otálora (Otálora et al., 2008) without a name in Scytinium. This we rectify here.

\section{Nomenclature}

Scytinium pulvinatum (Hoffm.) Otálora, P.M. Jørg. \& Wedin, comb. nov.

MycoBank 809005

Basionym: Collema pulvinatum Hoffm., Deutschl. Fl.: 104 (1796)

\section{Acknowledgements}

This study was supported by the Swedish Research Council (VR621-2009-537, VR621-20123990). The first author gratefully acknowledges support from a postdoctoral grant from Spanish Ministry of Education and Science (EDU3495/2010).

\section{References}

Jørgensen PM, Otálora MAG, Wedin M. 2013 - Proposal to conserve the name Leptogium (lichenized Ascomycota) with a conserved type. Taxon 62, 1333-1334.

Otálora MAG, Martínez I, Molina MC, Aragón G, Lutzoni F. 2008 Phylogenetic relationships and taxonomy of the Leptogium lichenoides group (Collemataceae) in Europe. Taxon 57, $907-$ 921. 
Otálora MAG, Jørgensen PM, Wedin M. 2013 (“2014”). A revised generic classification of the jelly lichens, Collemataceae. Fungal Diversity 64, 275-293. Published online 12/10 2013. DOI 10.1007/s13225-013-0266-1. 